\title{
Chlorosis, anaemia, and anorexia nervosa
}

\author{
I S L LOUDON
}

For nearly four centuries a disease known as chlorosis, the green sickness or the virgin's disease, was commonly recognised. There are many references to it in literature and art from the sixteenth to the nineteenth centuries ${ }^{1-3}$ and numerous clinical descriptions by physicians. Until the middle of the nineteenth century there was, however, no general agreement on the cause of the disease; then, after the development of haematology it was believed to be a form of hypochromic anaemia confined to young women. When the mystery of its aetiology seemed to have been solved, however, it was succeeded by another mystery: chlorosis, which had reached "epidemic proportions" throughout the eighteenth and nineteenth centuries, ${ }^{4}$ suddenly began to decline at the beginning of this century. Within two decades it had to all intents and purposes disappeared. ${ }^{5}$ Although various explanations were offered for its disappearance (usually along the lines of improvements in diet and living conditions) Witts remarked as recently as 1969 that "one is left with the uneasy feeling that the mystery of chlorosis, like that of Edwin Drood, remains unsolved." 4

Ths history of chlorosis is more clearly understood if it is divided into four phases:

(1) In the first phase, before 1750 , it was described as the "disease of virgins" or the "febris amatoria," a disorder due to "unrequited love."

(2) In the second phase, roughly 1750 to 1850 , it was generally believed to be a uterine disorder or a disorder of menstruation characterised by amenorrhoea.

(3) From 1850, with a complete change of ideas, it was considered to be a special form of anaemia peculiar to young women.

(4) In the final phase-the "Cheshire Cat" phase"-from 1900 to 1920 , chlorosis disappeared.

Sometimes it has been suggested that chlorosis was not a disease, sui generis, but a label applied to various wasting or debilitating diseases-phthisis, for example. But the clinical descriptions (at least up to 1850) were remarkably consistent, containing enough diagnostic features to separate chlorosis with confidence from other common debilitating disorders.

In this paper the clinical features of chlorosis will be reviewed and the hypothesis offered that chlorosis was not, as generally supposed, simply a form of anaemia (although anaemia occurred as a secondary feature) but a functional disorder closely related to anorexia nervosa.

\section{Prevalence of chlorosis}

Very little evidence of a statistical nature has been published about the prevalence of chlorosis before the end of the nineteenth century. Buchan in his Domestic Medicine ${ }^{7}$ implies that it was a common disorder in the eighteenth century, and Ashwell, in an excellent review published in 1836, remarked that "diseases of menstruation, especially chlorosis and amenorrhoea, are in this country of very frequent occurrence. ..."8 Hirsch" believed it was common throughout the nineteenth century in Europe, America, and the Middle and Far East, and that it had probably increased in frequency as the century progressed. Further evidence comes from the frequency of advertisements in the press which suggests that chlorosis was common in the late eighteenth and early nineteenth centuries. ${ }^{10}$ The most important

\section{The Mill House, Wantage, Oxfordshire OX12 9EH}

I S L LOUDON, DM, FRCGP, research associate, the Wellcome Unit for the History of Medicine in the University of Oxford; general practitioner epidemiological evidence, however, comes from the records of the dispensaries and the voluntary hospitals, which show that chlorosis was common among the poor during the latter half of the eighteenth and throughout the nineteenth centuries. An example of the dispensary records, which are particularly valuable as sources on the pattern of morbidity during the early industrial revolution, comes from the Finsbury Dispensary for the year 1800 (table I). Such lists were often published with comments on the prevailing diseases: in this instance that cases of amenorrhoea and chlorosis occurred in "more than their usual proportion." In the 12 monthly reports for 1800 , out of 3001 admissions* at the Finsbury Dispensary, $184(6 \cdot 1 \%)$ were for chlorosis, which was often the third or fourth most common disorder in the monthly list of diseases.

TABLE I-Monthily report of diseases 11 admitted under the care of the physicians of the Finsbury Dispensary, St Fohn's Square, Clerkenwell

\begin{tabular}{lrlr}
\hline List of diseases etc from 20 March to 20 April 1800 & \\
\hline Continued fever & 16 & Nephralgia calculosa & 1 \\
Scarlet fever & 2 & Pleurodyne & 3 \\
Measles & 1 & Hydrops & 4 \\
Sore throat & 4 & Hymorhis & 3 \\
Haemoptysis & 4 & Hysteria & 3 \\
Pulmonary complaints without fever & 53 & Paralysis & 3 \\
Phthisis pulmonalis & 12 & Apoplexy & 1 \\
Dysentery & 3 & Schrophula & 2 \\
Diarrhoea & 4 & Colica Pictonum & 1 \\
Chlorosis and amenorrhoea & 29 & Hypochondriasis & 1 \\
Leucorrhea & 7 & Insanity & 2 \\
Menorrhagia & 6 & Hooping cough & 4 \\
Asthenia & 10 & Rheumatism & 4 \\
Dyspepsia & 6 & Febricula & 4 \\
Enterodynia & 2 & Febris mesenterica & 3 \\
Peritonitis & 1 & Vermes & 8 \\
Constipation & 1 & Fever infantilis & 6 \\
Vertigo & 2 & Chronic cutaneous diseases & 15 \\
Cephalea & 5 & & \\
& & & \\
\hline
\end{tabular}

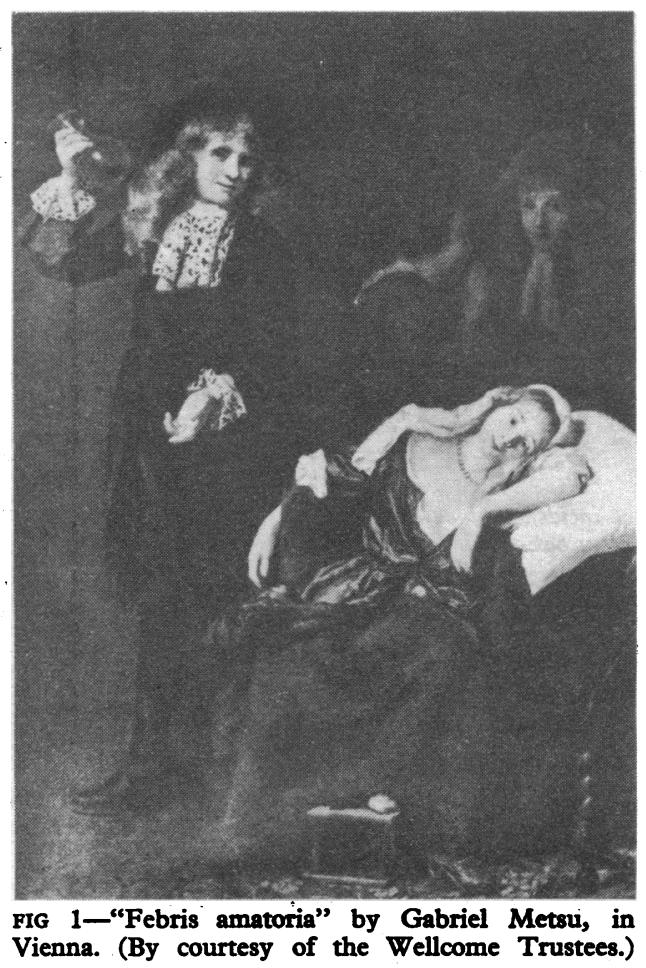

*The term "admissions" meant "admissions to the charity." It did not mean admission to inpatient beds, of which there were none at dispensaries. 
In the registers of dispensaries and hospitals chlorosis appeared sometimes under that heading, sometimes linked with amenorrhoea, and sometimes simply under the heading amenorrhoea. On other occasions, particularly in the eighteenth century, the terms suppression or obstruction of the menses were also used. ${ }^{12}$ There are several causes of amenorrhoea, the most obvious being physiological amenorrhoea due to pregnancy, lactation, or the menopause, and a temporary interruption of menstruation for a short time after the menarche before regular periods are properly established. Some of the cases that appeared in the registers must have been of such a nature. Menarche, for instance, was later than it is today, ranging "between the ages of 14 and 16, sometimes even later than 18; and sometimes indeed much earlier than 14,"13 and some cases of amenorrhoea may have been due to pregnancy, unrecognised or strenuously denied. But although we cannot be sure how many of the recorded cases of amenorrhoea were of physiological origin, such evidence as exists suggests they formed only a minority of the total recorded, and that secondary amenorrhoea, which was more common than it is today, occurred mainly as a feature of chlorosis. Menorrhagia and dysmenorrhea were also recorded at dispensaries and hospitals but, in contrast to consultations for menstrual disorders in general practice today, ${ }^{14}{ }^{15}$ were seen less frequently than amenorrhoea. This evidence is summarised in tables II and III, which show how common chlorosis was among the "proper objects of charity"- the patients of the dispensaries and infirmaries.

TABLE II-Number of admissions to dispensaries for amenorrhea and chlorosis, menorrhagia, and all menstrual disorders, expressed as total numbers and as percentages of total medical admissions to the dispensaries

\begin{tabular}{|c|c|c|c|c|c|c|c|c|}
\hline \multirow[t]{2}{*}{ Date } & \multirow[t]{2}{*}{ Dispensary } & \multicolumn{2}{|c|}{$\begin{array}{l}\text { Admissions for amenorrhea } \\
\text { and chlorosis }\end{array}$} & \multicolumn{2}{|c|}{$\begin{array}{l}\text { Admissions for } \\
\text { menorrhagia }\end{array}$} & \multicolumn{2}{|c|}{$\begin{array}{l}\text { Admissions for all } \\
\text { menstrual disorders }\end{array}$} & \multirow[t]{2}{*}{$\begin{array}{l}\text { Total medical admissions } \\
\text { to the dispensary }\end{array}$} \\
\hline & & No & $\%$ & No & $\%$ & No & $\%$ & \\
\hline 1774 & $\begin{array}{l}\text { General } \\
\text { Dispensary } 17\end{array}$ & 29 & 1.7 & $\begin{array}{l}\text { London } \\
\mathbf{2 2}\end{array}$ & $1 \cdot 3$ & 51 & $3 \cdot 1$ & 1662 \\
\hline $1775-6$ & $\begin{array}{l}\text { The Westminster } \\
\text { General }^{18}\end{array}$ & 12 & 0.9 & 20 & 1.5 & 32 & $2 \cdot 4$ & 1320 \\
\hline 1800 & $\begin{array}{l}\text { Finsbury } \\
\text { Dispensary10 }\end{array}$ & 128 & $4 \cdot 6$ & 74 & $2 \cdot 7$ & 202 & $7 \cdot 3$ & 2771 \\
\hline 1811 & $\begin{array}{l}\text { Western } \\
\text { Dispensary's0 }\end{array}$ & 36 & $2 \cdot 8$ & 4 & 0.3 & 42 & $3 \cdot 3$ & 1283 \\
\hline 1801 & $\begin{array}{l}\text { Public } \\
\text { Dispensary }\end{array}$ & 78 & $2 \cdot 2$ & 38 & $1 \cdot 1$ & 116 & $3 \cdot 3$ & 3508 \\
\hline 1804 & $\begin{array}{l}\text { Liverpool } \\
\text { Dispensaryss }\end{array}$ & 208 & $2 \cdot 0$ & $\begin{array}{l}\text { Provincial } \\
97\end{array}$ & 0.9 & 315 & $2 \cdot 9$ & 10350 \\
\hline 1801 & $\begin{array}{l}\text { Bath City } \\
\text { Dispensary }\end{array}$ & 19 & 1.5 & 14 & $1 \cdot 1$ & 33 & $2 \cdot 6$ & 1222 \\
\hline 1808 & $\begin{array}{l}\text { Plymouth } \\
\text { Dispensary }\end{array}$ & 134 & $3 \cdot 3$ & 55 & 1.4 & 194 & $4 \cdot 8$ & 4010 \\
\hline 1808 & $\begin{array}{l}\text { Norwich } \\
\text { Dispensary } 25\end{array}$ & 18 & $2 \cdot 9$ & 10 & 1.6 & 29 & $4 \cdot 7$ & 611 \\
\hline 1818 & $\begin{array}{c}\text { Combined Dublin } \\
\text { Dispensaries }\end{array}$ & 285 & 1.6 & 165 & 0.9 & 450 & $2 \cdot 6$ & 17269 \\
\hline
\end{tabular}

TABLB III-Number of admissions to the outpatient departments of various hospitals for amenorrhea and chlorosis, menorrhagia, and all menstrual disorders, expressed as total numbers and as percentages of all admissions

\begin{tabular}{|c|c|c|c|c|c|c|c|c|}
\hline \multirow[t]{2}{*}{ Date } & \multirow[t]{2}{*}{ Hospital } & \multicolumn{2}{|c|}{$\begin{array}{l}\text { Admissions for amenorrhea } \\
\text { and chlorosis }\end{array}$} & \multicolumn{2}{|c|}{$\begin{array}{c}\text { Admissions for } \\
\text { menorrhagia }\end{array}$} & \multicolumn{2}{|c|}{$\begin{array}{l}\text { Admissions for all } \\
\text { menstrual disorders }\end{array}$} & \multirow[t]{2}{*}{$\begin{array}{c}\text { Total } \\
\text { admissions }\end{array}$} \\
\hline & & No & $\%$ & No & $\%$ & No & $\%$ & \\
\hline 1799 & \multirow{3}{*}{$\begin{array}{l}\text { Westminster } \\
\text { Hospital } \\
\text { Bristol } \\
\text { Infirmary }\end{array}$} & 51 & $4 \cdot 4$ & 12 & 1.0 & 63 & $5 \cdot 5$ & 1153 \\
\hline 1760 & & 63 & $4 \cdot 2$ & 14 & 0.9 & 77 & $5 \cdot 1$ & 1165 \\
\hline $\begin{array}{l}1800 \\
1820 \\
1840 \\
1806\end{array}$ & & $\begin{array}{l}40 \\
11 \\
35 \\
60\end{array}$ & $\begin{array}{l}5 \cdot 1 \\
1 \cdot 4 \\
3 \cdot 2 \\
3 \cdot 9\end{array}$ & $\begin{array}{r}10 \\
5 \\
3 \\
10\end{array}$ & $\begin{array}{l}1.3 \\
0.6 \\
0.3 \\
0.7\end{array}$ & $\begin{array}{l}50 \\
16 \\
38 \\
70\end{array}$ & $\begin{array}{l}6.4 \\
2 \cdot 1 \\
3.5 \\
4.6\end{array}$ & $\begin{array}{r}783 \\
800 \\
1104 \\
1522\end{array}$ \\
\hline 1837 & $\begin{array}{l}\text { Nottingham } \\
\text { General } \\
\text { Radcliffe } \\
\text { Infirmary } \\
\text { Oxford }\end{array}$ & 10 & 5 & \multicolumn{2}{|c|}{ No record } & 15 & $7 \cdot 5$ & 200 \\
\hline
\end{tabular}

Sources: Records of Bristol Royal Infirmary. Bristol Records Office, The Council House, Bristol. Records of the Radcliffe Infirmary. Archives: Oxfordshire Area Health Authority (Teaching), Oxford. Records of the Radcliffe Infirmary. Archatient admissions are included.

TABLB IV-Age-incidence of cases of chlorosis and amenorrhea and of cases of menorrhagia at outpatients department at Bristol Royal Infirmary

\begin{tabular}{|c|c|c|c|c|c|c|}
\hline & \multicolumn{6}{|c|}{ Age groups } \\
\hline & $10-14$ & $15-24$ & $25-34$ & $35-44$ & $45-54$ & Total \\
\hline & \multicolumn{6}{|c|}{ Amenorrhea and chlorosis } \\
\hline $\begin{array}{l}1760 \\
1800 \\
1840\end{array}$ & $\begin{array}{l}1 \\
1 \\
1\end{array}$ & $\begin{array}{l}35 \\
33 \\
26\end{array}$ & $\begin{array}{r}22 \\
6 \\
7\end{array}$ & $\begin{array}{l}4 \\
1\end{array}$ & 1 & $\begin{array}{l}63 \\
40 \\
35\end{array}$ \\
\hline \multicolumn{7}{|c|}{ Menorrhagia } \\
\hline $\begin{array}{l}1760 \\
1800 \\
1840\end{array}$ & & 1 & $\begin{array}{l}5 \\
3 \\
2\end{array}$ & $\begin{array}{l}6 \\
4 \\
1\end{array}$ & $\begin{array}{l}2 \\
3\end{array}$ & $\begin{array}{r}14 \\
10 \\
3\end{array}$ \\
\hline
\end{tabular}

Source: Outpatient registers, Bristol Royal Infirmary, Bristol Records Office, The Source: Outpatient regist

\section{Clinical features of chlorosis}

\section{AGE, SEX, AND SOCIAL CLASS}

A few authors maintained that chlorosis could occur in men ("the young and delicate of the male sex") ${ }^{13}$; others maintained it was exclusively a disorder of women ${ }^{16}$ and everyone was agreed that if it occurred in men it was only very rarely. Chlorosis was essentially a disease of young women and typically it was a disorder of virgins, or the unmarried, or occasionally the married but childless. Johannes Lange, in 1554, in what was probably the earliest published account of the disease ${ }^{20}$ called it the "disease of virgins" and pointed out the obvious cure: "I instruct virgins afflicted with the disease that as soon as possible they live with men and copulate, if they conceive they recover. ..."

When it came to considerations of social class, most physicians before the mid-nineteenth century believed that chlorosis was, or certainly ought to be, a disorder of the affluent. Lettsom in $1795^{\circ 0}$ and 
Laycock in $1840^{31}$ believed that girls' boarding schools were, for instance, breeding grounds of chlorosis. This connection between chlorosis and affluence was put most clearly by Scott when he wrote that a young woman of the affluent classes saw herself placed on a pinnacle "from which the least lapse of conduct would precipitate her into utter contempt. ... No wonder then that her full bosom should swell so much with hopes and fears occasioning that languid and desponding state of mind in which the sympathising body soon participates." Chlorosis, in his view, was caused by sexual frustration, and therefore, "If our hypothesis be well founded, we should very seldom meet with the disease in the lower classes of females or, at least, much less frequently than in the middling and higher classes ... the disease too should be almost unknown in savage life."32 A similar view was held as late as 1875 by Gaillard Thomas who maintained that chlorosis :

is an affection of great frequency in all civilised societies and refined communities. The greater the tendency developed by society to luxurious and enervating habits the more frequently it is encountered. Thus in large cities and the higher walks of life it is of much more common occurrence than in country places and among the lower classes. ${ }^{33}$

Those physicians whose experience lay wholly in private practice could believe in the essential connection between chlorosis and feminine purity and delicacy among the affluent; those with appointments at hospitals and dispensaries could not. Sir Gilbert Blane, for instance, who was physician to St Thomas's Hospital, found that the prevalence of "diseases peculiar to women" was similar in hospital and private practice. ${ }^{34}$

Robert Willan, the "father of dermatology" and physician to the Public Dispensary for 21 years, was well aware that chlorosis was not confined to the rich:

Young females are often affected with (chlorosis) who follow a sedentary occupation in close streets or narrow crowded tenements, and seldom enjoy the benefits of fresh air. The disorder is not, however, confined to this class of people. We cannot be surprised that young ladies of the highest rank should suffer equally: eight months of the year they sit on thick carpets, in close rooms, heated by register-stoves; have large fires kept in their rooms, never stir out except in carriages, and are often too much restricted in their diet. ${ }^{35}$

Willan and Blane, who shared an interest in a statistical approach, were among the first to appreciate how common chlorosis was among the poor.

In the third phase of the history of chlorosis-the phase of anaemia-there was a change of emphasis. Chlorosis, from the midnineteenth century was believed to be mostly a disease of servants in basements and working-class girls in dark and unhealthy tenements and factories, caused by poor nutrition and the absence of fresh air and sunlight. Nevertheless, clinical experience showed that it often occurred in private and public patients alike. Clifford Allbutt summed up his views in 1898: "The chlorotic girl is well-known in every consulting room, public or private,"36 a conclusion similar to Sir Gilbert Blane's a century earlier. It is impossible to determine retrospectively whether chlorosis was in fact more common among the affluent or the poor; but it seems certain that it was a common diagnosis in all social classes.

The age of onset of chlorosis is illustrated in table IV where, in contrast to cases of menorrhagia, chlorosis and amenorrhoea occurred sometimes as early as 14 but predominantly in the age group 15-24; most of the later cases were described as relapses. Lettsom (1795) ${ }^{30}$ and Buchan $(1805)^{7}$ describe it as a disease that followed puberty, Ashwell $(1836)^{8}$ as a disease that was seen "at a time when puberty is, or ought to be, established." Stockman (1895) ${ }^{37}$ wrote that "out of my 63 cases of chlorosis . . 41 were between the ages of 15 and 20 , and the highest age of the first attack was 23." Osler $(1898)^{38}$ put the onset between the ages of 14 and 17. The evidence from all sources in the eighteenth and nineteenth centuries is remarkably consistent: chlorosis occurred in puberty and adolescence and it was common among the daughters of the rich and the poor.

\section{AMENORRHOEA}

Amenorrhoea, as we have seen, was so much the cardinal feature of chlorosis that between 1750 and 1850 the two words were often used synonymously. The older term "obstruction of the menses" illustrated the underlying belief that in amenorrhoea the menstrual discharge was still being formed, but it was being reabsorbed, causing the development of crude humours throughout the body. Johannes Lange believed the menstrual blood flowed from the liver to the womb and, if outflow was suppressed or obstructed, it was carried back through

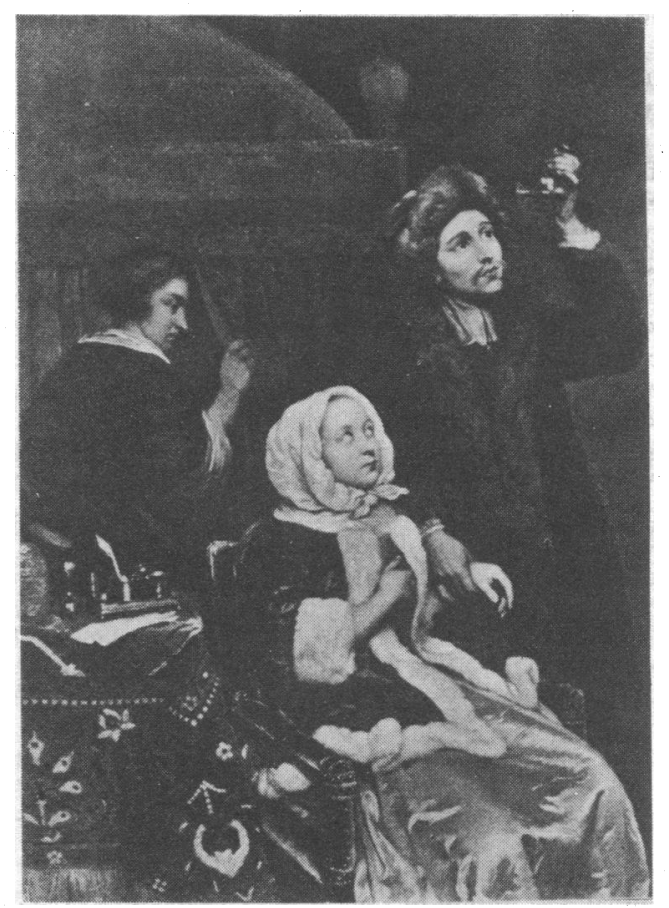

FIG 2- "Mal d'amour" by Gerrit Dou, in Buckingham Palace. (By courtesy of the Wellcome Trustees.)

the vena cava and the large arteries; ". . . a good part is distributed to the head, so grave accidents appear in the viscera. . . ."29 Many of the symptoms of chlorosis were therefore attributed to the reabsorption of "bad" menstrual blood. Such beliefs were common until the midnineteenth century, and a surgeon, Samuel Fox, who wrote that "Chlorosis ... is one of the most difficult and annoying maladies in general practice" was one of the first to assert firmly that menstrual blood was normal healthy blood.13 But, whatever views were held about the effects of amenorrhoea it remained, until the phase of anaemia, the pathognomic feature of chlorosis.

\section{MENTAL STATE}

Just as chlorosis caused amenorrhoea and amenorrhoea, untreated, would inevitably lead to chlorosis, ${ }^{8}$ so a disturbed mental state in a susceptible girl could cause the disease or, alternatively, be caused by it. Lange (1554) believed that "the filthy blood of the menses" being absorbed and travelling to the head caused the patient to become foolish and delirious. ${ }^{29}$ Buchan (1805) referred to the dangers to a girl with a "lazy indolent disposition ... a grave moping melancholy creature. ..." Such were susceptible to chlorosis. ${ }^{7}$ Lettsom (1795) wrote of female weaknesses and reluctance to exertion ${ }^{30}$; Laycock (1840) gave a vivid picture of the tendency for chlorosis to develop when a girl returned from boarding school: ". . . a hysterical wayward capricious girl, imbecile in mind, habits and pursuits, prone to hysteric paroxysms upon any mental excitement. . .."31

Ashwell (1836) wrote of: "functional affections of the cerebrum" causing "hysteria, chorea, epilepsy, vertigo, temporary loss of memory and acuteness of perception ..."8 in chlorosis, and Barker (1843) wrote of langour and debility of mind: "nights restless and mornings heavy." 39 The mental symptoms, it is important to note, were present from the outset of the illness: "Sadness, nervousness, and irascibility mark its onset ... langour, sadness, and aversion to company usually first attract attention,"38 while symptoms such as dyspnoea, palpitations, and neuralgic pains clearly had a functional basis. The mental state in chlorosis seems to have been most often a state of depression, hypochondria, weakness, langour, debility, and retreat indoors from the world outside.

\section{DISTURBANCE OF APPETIT}

A constant feature of chlorosis was a "capricious or depraved" appetite. This included anorexia, or at least a reduced food intake, 
sometimes associated with nausea and vomiting. Meat, especially red meat, was avoided or only burnt and blackened fragments were eaten. ${ }^{36}$ Often there was a longing for foods of acid taste. But the striking feature was "pica" consisting of the eating of indigestible materialscinders, egg shells, sealing wax, slate, pencil, chalk, earth, "and such trash" being devoured. ${ }^{8333638}$ Such habits were a well-known feature of chlorosis from the earliest references to the disease ${ }^{40}$ into the nineteenth century. Laycock maintained that the choice of material was "directed to something dry and tasty-something that will endure mastication and make a pleasant crackle. I believe there are very few young women that do not eat rice or unground coffee; more rarely, hard herring uncooked, or salt, mortar, chalk, cinders, sealing-wax, and other dry, tasty, crackly edibles." 31 Pica was so bizarre a feature that it dominated the picture of the depraved appetite and was ultimately ascribed to iron deficiency; but the only evidence for this seems to have been that it occurred in chlorosis and chlorosis was believed to be a form of anaemia. There are, however, many accounts of severe loss of weight in chlorosis, often amounting to emaciation, ${ }^{8} 313539$ and it was recognised that death could occur either from self-starvation per se or from increased susceptibility to phthisis. Clifford Allbutt believed that "a panic fear of obesity" caused the depraved appetite ${ }^{36}$ and, interestingly, Laycock ${ }^{31}$ described examples of "bulimia" (excessive overeating) alternating with anorexia.

\section{THE GREEN COLOUR}

The green colour is the best known feature of chlorosis, but Lange in his original description in $\mathbf{1 5 5 4}$ made no reference to green nor did he use the term chlorosis; the term was in fact first used by Jean Varandal, professor at Montpellier, in 1615.41 This leads to the question, was there really a green complexion from which the disease derived its name and, if there was, what caused it? Some maintained the colour was so characteristic it could be recognised at a glance; others that only with the eye of faith could it be detected at all. Varandal certainly believed in a green colour, heading his chapter "On chlorosis or the abnormal skin colour of virgins ..." and he referred to the change in skin colour from white to green ("ex albo ut plurimum viriscente"); but then he confused the issue by pointing out that "every lover should be pale; this is the colour suitable for love" so that "virgins and young unmarried women" may grow pale not by nature but by cosmetic art, although, he conceded, climate, diet, and other causes might be responsible.

$\mathrm{H}$ St $\mathrm{H}$ Vertue, in an ingenious but whimsical and unconvincing paper, attempted to relate chlorosis to tight corsetting, invoking compression and displacement of the abdominal organs as the cause of the symptoms. ${ }^{2}$ But, whatever explanation is attempted, when the actual descriptions of observers of the disease are examined the probability of a green complexion begins to fade. In the following list (arranged in chronological order) the facial appearance was described as :

\section{Sadly pallid ${ }^{29}$}

1730 Wan, sallow complexion ${ }^{42}$

1781 Pale and yellowish ${ }^{43}$

1795 Pale and sallow ${ }^{30}$

1801 Pale $^{35}$

1830 There is sometimes a .. slight tinge of green, of yellow or of slate colour ${ }^{45}$

1833 Paleness. .. . with an icteroid tinge ${ }^{46}$

1836 Universal pallor ${ }^{8}$

1839 Sallow $^{12}$

1843 Pallid, leaden and pasty ${ }^{39}$

1860 A greenish hue ${ }^{46}$
1825 Greenish yellow ${ }^{44}$

1864 Pale or greenish ${ }^{48}$
1875 A light green colour ${ }^{33}$

1881 Green-ness of the complexion $^{49}$

1882 General hue decidedly yellow ${ }^{50}$

1892 A curious yellow green tinge ${ }^{16}$

1908 Alabaster white ... sometimes yellowish ... . only very seldom greenish ${ }^{51}$

1925 (with) a great deal of imagination ... the slightest imaginable tinge of olive green in the shadow beneath the chin and that is all ${ }^{52}$
Out of 19 descriptions, only three are definitely green, three greenish or possibly green, and two yellowish green.

It seems that a green colour was recorded most often during the second half of the nineteenth century, a long time after the term green sickness was introduced, and possibly many saw green-ness because they believed they ought to. Bias in the interpretation of physical signs is by no means uncommon in clinical medicine. ${ }^{53}$ If that is what happened, then the origin of the term green sickness may have been the use of the word "green" as a description of inexperience or innocence. "Chlorosis" may have been a literal translation of this metaphorical usage of the word green, for the use of green to indicate "of tender age, youthful ... immature, raw, inexperienced" can be traced backat least to the sixteenth century (Oxford English Dictionary). By mistranslation from the French, Cinderella's green slipper became a glass slipper. In similar fashion the green of virginal immaturity may have become chlorosis which then became a green face. Robert Louis Stevenson may have been thinking of this original use of the term when he wrote: "There is some meaning in the old theory of wild oats; and a man who has not had his green sickness and got done with it for good, is as little to be depended upon as an unvaccinated infant." ${ }_{54}$

Hudson, having reviewed the evidence, believes that on the subject of the green complexion we must "go no further than a suspension of judgment." ${ }_{55}$ Perhaps the last word should rest with Professor L J of Witts who writes (personal communication 1979): "I never saw a green chlorosis. Sir William MacArthur used to say the Black Death didn't mean that people turned black but that it was a very nasty illness. In the same way, chlorosis was a green sickness, the sickness of youth or immaturity."

There is therefore sufficient doubt about the green colour to justify removing it from its position as the most characteristic feature of $i_{i}$ chlorosis. If it is excluded the cardinal features of the disease were: the characteristic age and sex incidence; the clear association with o mental disturbance; amenorrhoea, or at least scanty menses; a Oु pronounced disturbance of appetite including anorexia and pica; usually loss of weight; and a normal expectation of recovery but also a tendency to relapse in the third or fourth decades of life.

\section{Aetiology of chlorosis}

There were many different beliefs on the cause of chlorosis. At first, as we have seen, it was attributed to love-sickness or sexual frustration: a belief that made it an irresistible subject for ribald or $\stackrel{\mathbb{D}}{工}$ romantic treatment by painters, poets, and dramatists. This belief was $\vec{\varphi}$ generally held until the end of the eighteenth and beginning of the nineteenth century when a blend of psychogenic, organic, and environmental factors was accepted as the cause of chlorosis. Jewson ${ }^{56}$ has described this as the era of "bedside medicine" when pathology was speculative and broadly based (today we would call it "whole person medicine"). This was followed by the era based on organ pathology which, in turn, was followed in the second half of the nineteenth century by the era of laboratory medicine. The evolution $\varrho$ of ideas about chlorosis followed this pathway. Cullen ${ }^{43}$ described the $\overrightarrow{\vec{O}}$ cause as "a general flaccidity" of the system. Lettsom, ${ }^{30}$ Willan, ${ }^{35} 3$ and John Reid ${ }^{57}$-all three noted dispensary physicians-blamed a combination of nervous influences, unsuitable environment, and poor diet. With the era of organ pathology the liver was the root of the illness according to Fox, while Virchow believed in a "hypoplasia of the arterial system" and most believed the fault lay with the generative organs and "deficient uterine action." Sir Andrew Clark thought the cause was "ptomaines" absorbed from a constipated bowel. All these ideas were displaced in the era of laboratory medicine by the belief, $\delta$ still generally held today, that chlorosis was simply a form of anaemia. Clinical haematology was born when the first red cell count was made 0 in 1852 and the first haemoglobinometer devised in 1876.58 Although suggestions that the blood might be affected in chlorosis were made $\mathcal{N}$ as early as $1830,{ }^{59}$ general acceptance of the theory of anaemia only $>$ came some 40 or 50 years later. By 1890 it was accepted that "there are two great and direct causative factors in chlorosis, namely blood $\bar{N}$ loss and an insufficient supply of iron in the diet." 37 The influential $\stackrel{N}{\circ}$ Clifford Allbutt (1898) was quite definite: "Chlorosis is a malady ... $\omega$ (which) consists in defects in the red corpuscles of the blood, a defect partly in numbers, chiefly of haemoglobin; the plasma being constant 0 or even enriched." 36

He was scornful of such ideas as sexual frustration or love sickness $\stackrel{\oplus}{\rightarrow}$ playing any part, which he dismissed as "the fanciful views that have 0 prevailed amongst physicians and poets." In a passage memorable for ${ }_{0}^{\circ}$ the light it throws on Victorian ideas about sexual pathology, he wrote $\mathbb{D}$ that the attribution of chlorosis to "perverted or to thwarted sexual $\overrightarrow{\mathbb{D}}$ impulses is mistaken" because of the absence of any post-mortem $\triangle$ evidence of thwarted sexual desire; but, he added, "if epithelial debris be found repeatedly in the urine, masturbation must not be forgotten, 8 and corroborative evidence of the habit may be detected." Amenorrhoea, in his view, exemplified the wisdom of the body, protecting the patient from blood loss. The worst cases of chlorosis were those with normal or heavy menses, for very slight loss of blood in established chlorosis "will intensify the impoverishment of the blood beyond all expectation." Attempts to restart menstruation were unwise, and he 
quoted the advice of a medical friend who, when faced with troublesome mothers, would say: "Madam, when the works are put in order the clock will begin to strike."

There were two good reasons why the theory of anaemia was accepted eagerly. Firstly, it fitted with the new era of scientific laboratory medicine ${ }^{60}$; secondly, it absolved doctors from embarrassing and suggestive inquiries into the menstrual state and sexual aspirations of their female patients at a particularly delicate and modest stage of their lives. Traditional suggestions of cure "by the exercise of venery" were not only disgusting but impractical since girls afflicted with chlorosis had neither inclination nor energy for such exercise. ${ }^{13}$ An age that regarded erotomania, nymphomania, and onanism as likely causes of insanity, or even death, was not one that could accept Lange's robust advice. The mystery of chlorosis seemed to have been solved: it was anaemia, and you examined the blood, confirmed the diagnosis, and prescribed Blaud's pills. At first it was thought that the blood picture was specific and easily distinguished from other hypochromic anaemias. Later this was shown to be untrue. ${ }^{32}{ }^{57}$ Although there is little doubt that hypochromic anaemia occurred in chlorosis, the belief that chlorosis was simply a form of anaemia can no longer be accepted.

\section{Chlorosis as a form of anaemia}

Eliciting the history of an illness is apt to be a selective process; significant symptoms are sought and those that lend support to the latest ideas become the prominent, significant, pathognomonic symptoms. So it was with chlorosis. Once it had been established that chlorosis was a form of anaemia all attention focused on the blood while symptoms of mental disturbance, amenorrhoea, perverted appetite, and anorexia received much less attention. Tiredness, palpitations, and dyspnoea, on the other hand, were accepted as evidence of anaemia, but it is important to note that these symptoms were always present in full force from the very onset of chlorosis, for it is now known that they occur only in the later stages of a chronic anaemia. So far as the severity of anaemia is concerned, Naegli maintained that in mild cases the haemoglobin concentrations and red cell counts were normal or only minimally reduced (haemoglobin $90-100 \%$ and RBCs 4.5-5 million) while haemoglobin concentrations in moderate cases were $50-60 \%$ and in severe cases $20-30 \%{ }^{51}$ The argument is whether the anaemia was the primary cause of the illness or whether it was a secondary anaemia.

The main argument against the anaemia being the primary cause is its inherent unlikeliness. No known form of primary anaemia causes amenorrhoea and is so narrowly restricted to a youthful age group in one sex. No form of hypochromic anaemia induces anorexia, depraved appetite and pica, and weight loss sometimes amounting to emaciation. Menstrual loss (which was the popular explanation of the anaemia) cannot be the cause of anaemia when the characteristic menstrual pattern is not menorrhagia but amenorrhoea. No form of anaemia consistently produces gross and obvious types of mental and emotional derangement, least of all when they precede the changes in the blood.

Not every country accepted the anaemia theory whole-heartedly. In France in 1874 chlorosis was regarded as being both an anaemia and a nervous complaint: “. . . une affection qui sert de trait d'union entre celles du sang et celles des nerfs; entre les dyscrasies sanguines et les nevroses." 11 In New York in 1875 Gaillard Thomas, professor of obstetrics and diseases of women and children, rejected the theory of anaemia outright. ${ }^{33} \mathrm{He}$ drew up a table contrasting anaemia and chlorosis and showed convincingly the inconsistencies of the anaemia theory, adding "It is a well-known fact that the disease may exist in aggravated form with little or no blood change." $\mathrm{He}$, and Naegli, ${ }^{52}$ both believed that anaemia when it occurred was a secondary feature due to the disturbance of appetite. Nevertheless, when the means became available for measuring haemoglobin in the latter part of the nineteenth century, there is no doubt anaemia, often of severe degree, often occurred in cases diagnosed as chlorosis. Almost certainly this was due to the fact that, once the theory that chlorosis was a form of anaemia became widely accepted, any young woman with pallor and anaemia was likely to be labelled as a case of chlorosis. There is indeed supporting evidence for this proposition.

Anaemia from blood loss due to acute gastric ulcers was common in young women at the end of the nineteenth century and continued until the third or fourth decades of this. Osler records this clearly, ${ }^{16}$ and Robb Smith (personal communication 1979) recalls seeing many such cases at St Bartholomew's Hospital about 1930, but ten years later at Oxford there were few or none. Such cases were often indexed as

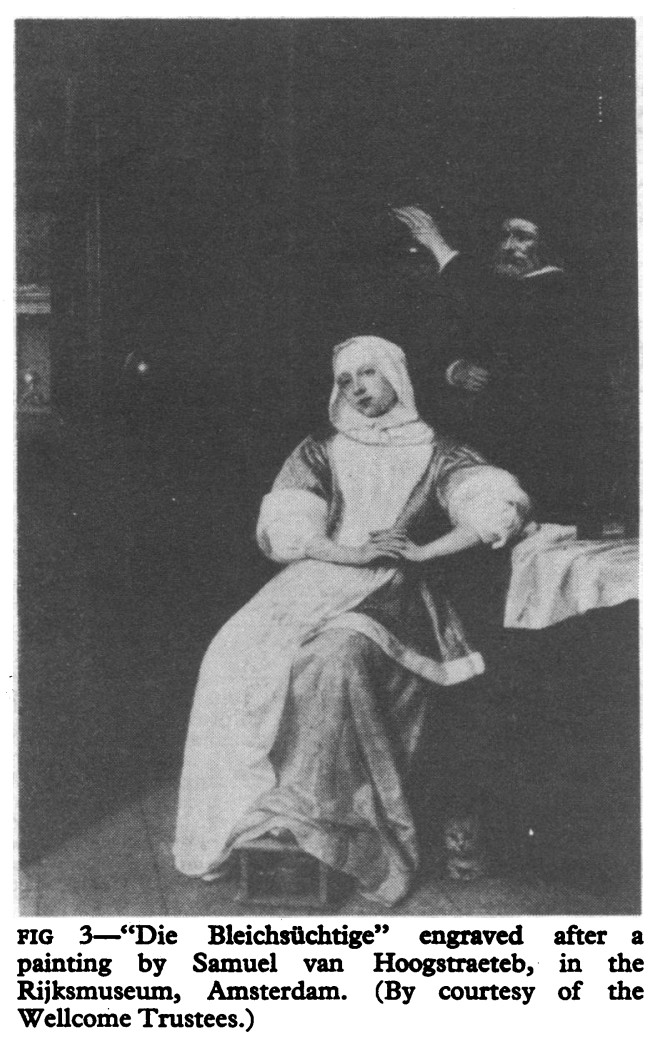

chlorosis, as Campbell pointed out in his review of chlorosis at Guy's Hospital, where they appeared under the title "haematemesis and chlorosis." It is notable that out of 58 cases of chlorosis at Guy's between 1890 and 1907 only 12 had amenorrhoea, the rest having normal, irregular, or scanty menses, although amenorrhoea was previously regarded as an essential feature of chlorosis. It seems likely that, by the latter part of the nineteenth century, the term "chlorosis" included at least three kinds of disorder common in young women: (1) true chlorosis, sometimes with secondary anaemia; (2) iron deficiency anaemia due to poor diet or heavy menses or both; and

(3) anaemia due to blood loss from gastric ulcers.

The situation was further confused by the gradual discarding of the term "chlorosis" as old-fashioned and its replacement by "anaemia" in various forms. A study of the inpatient registers at Bristol Royal Infirmary showed how this change took place. ${ }^{.2}$ Throughout the nineteenth century about $2 \%$ of all medical admissions consisted of young women (mostly domestic servants) between the ages of 15 and 25. In the first two-thirds of the century most of these were indexed as either "chlorosis" or "amenorrhoea." After that the terms used were "anaemia, anaemia and hysteria, anaemia and debility, and anaemia and dyspepsia," and the number of admissions increased. It follows that the apparent rise in the prevalence of chlorosis towards the end of the nineteenth century and the subsequent fall must be interpreted with caution. Some of the changes were probably no more than changes in nomenclature. Paradoxically, the era of laboratory medicine, which on the whole was so triumphantly successful in clarifying our understanding of diseases, actually confused the picture so far as chlorosis was concerned. The most consistent and reliable accounts of chlorosis are therefore to be found among those published before 1850. When those accounts are compared with descriptions of anorexia nervosa as it occurs today (table $V$ ) the similarities are so compelling that it seems reasonable to postulate a common underlying basis to the two disorders.

\section{Chlorosis and anorexia nervosa}

Richard Morton in 1694 is credited with the description of two cases of anorexia, but the term was first used by Sir William Gull who described the disorder as "apepsia hysterica" in 1868 and renamed it "anorexia nervosa" in 1874..$^{\circ 3}$ Simultaneously and independently, Lasegue in France described the condition as "anorexia hysterique." Gull believed it to be a "central 
rather than a 'peripheral' condition in which the want of appetite is, I believe ... due to a morbid mental state." $\mathrm{He}$ noted that young women of the age when anorexia occurred "are especially obnoxious to mental perversity," using "obnoxious" not in its present pejorative sense, but as "liable or susceptible to harm." He believed the illness was characterised by hyperactivity and drew attention to the remarkable disparity between the capacity for physical exercise and the rapidly increasing emaciation. His description of anorexia has hardly been bettered, although it is now recognised that hyperactivity is not always found in anorexia nervosa. If Gull did not see a connection between chlorosis and anorexia nervosa it may have been partly because of the difference in the mental state, but even more because chlorosis was regarded in 1874 as anaemia and symptom of regressive behaviour. Pica is a common habit among healthy infants and small children as they explore the world and their own sensations; persistent pica in adolescents, however, suggests psychiatric disturbance. Marshall Hall, a 3 perceptive observer of chlorosis, noted that the patient with $\mathbb{\mathbb { D }}$ chlorosis liked to have indigestible substances in her mouth $c$. "but especially when affected by agitation or anxiety." 45 Whatever explanation is offered for this curious habit, some of the substances that were commonly swallowed-particularly claycould have interfered with iron absorption and contributed to, or caused, anaemia. ${ }^{55}$

Karl Figlio, who shares the view that chlorosis cannot have $\stackrel{\varnothing}{\varnothing}$ been simply a form of anaemia, remarks that: "Chlorosis was one form of sexually based pathology-in this case it was marked

TABLE V-A comparison of the features of chlorosis and anorexia nervosa

\begin{tabular}{|c|c|c|}
\hline & Chlorosis & Anorexia nervosa \\
\hline First described & $\begin{array}{l}\text { By Johannes Lange in 1554, but not named } \\
\text { chlorosis until } 1619 .\end{array}$ & $\begin{array}{l}\text { By Sir William Gull in } 1874 \text { and at same time } \\
\text { and independently by Lasègue in France }\end{array}$ \\
\hline Sex incidence & Occurred in women; seldom if ever in men & $\begin{array}{l}\text { Predominantly in women, but sometimes in men. } \\
\text { Ratio of } 9(\mathrm{~F}): 1(\mathrm{M}) \text { has been described }\end{array}$ \\
\hline Age incidence & $\begin{array}{l}\text { Usual range } 14-23 \text { with peak incidence } 19-20 \text {. } \\
\text { Older cases were usually relapses }\end{array}$ & $\begin{array}{l}\text { Most cases occur between } 13 \text { and } 20 \text { with a peak age } \\
\text { of } 17-18 \text {; but cases can occur later in life }\end{array}$ \\
\hline Social class & $\begin{array}{l}\text { Seems to have been common among affluent } \\
\text { and poor, although relative incidence in terms } \\
\text { of social class in unknown }\end{array}$ & Said to be mostly a disorder of middle classes \\
\hline Prevalence & $\begin{array}{l}\text { Very common from at least mid-18th century } \\
\text { until beginning of 20th }\end{array}$ & $\begin{array}{l}\text { A common disorder that is currently increasing in } \\
\text { frequency }\end{array}$ \\
\hline Amenorrhea & $\begin{array}{l}\text { Nearly always present, but sometimes scanty } \\
\text { menses or, rarely, normal menses }\end{array}$ & Invariable \\
\hline $\begin{array}{l}\text { Appetite and } \\
\text { food intake }\end{array}$ & $\begin{array}{l}\text { Anorexia usual and a "depraved appetite" } \\
\text { (pica) seems to have been very common. Meat } \\
\text { usually avoided. }\end{array}$ & $\begin{array}{l}\text { Anorexia-or at least food-avoidance-is always } \\
\text { present. Meat usually avoided }\end{array}$ \\
\hline $\begin{array}{l}\text { Nausea and } \\
\text { vomiting }\end{array}$ & Very common & Common \\
\hline $\begin{array}{l}\text { Anaemia and } \\
\text { hypoproteinaemia }\end{array}$ & $\begin{array}{l}\text { Probably anaemia was common as a secondary } \\
\text { feature of chlorosis, and reduced plasma } \\
\text { protein may also have occurred, but picture } \\
\text { confused by inclusion of other types of anaemia }\end{array}$ & $\begin{array}{l}\text { Both can occur in anorexia nervosa but only } \\
\text { rarely }\end{array}$ \\
\hline Loss of weight & $\begin{array}{l}\text { A common, but not an invariable feature; but on } \\
\text { many occasions emaciation could occur }\end{array}$ & $\begin{array}{l}\text { Invariable, often amounting to between } 25 \% \text { and } 50 \% \\
\text { of total body weight. Emaciation can be extreme }\end{array}$ \\
\hline Mental state & $\begin{array}{l}\text { Mental disturbance invariable and usually } \\
\text { presenting feature; most often a form of } \\
\text { melancholia but many different kinds of } \\
\text { disturbance described }\end{array}$ & $\begin{array}{l}\text { Invariably some kind of mental disturbance occurs } \\
\text { whether in the form of hysteria, obsessional } \\
\text { neurosis or a depressive state, or in the form } \\
\text { of a psychosis. Follow-up in later life often } \\
\text { shows a continuation of mental disorder }\end{array}$ \\
\hline $\begin{array}{l}\text { Facial } \\
\text { appearance } \\
\text { Relapses }\end{array}$ & $\begin{array}{l}\text { Some kind of pallor always described; whether } \\
\text { it had a green tinge is debatable } \\
\text { Commonly occurred in chlorosis }\end{array}$ & $\begin{array}{l}\text { A part from thinness, no special change in facial } \\
\text { appearance and not usually any noticeable pallor } \\
\text { Common. According to some authors, most patients } \\
\text { experience further attacks or display crippling } \\
\text { disorders of personality }\end{array}$ \\
\hline Prognosis & $\begin{array}{l}\text { Opinions varied, but death could occur in a } \\
\text { minority either from inanition or from increased } \\
\text { susceptibility to phthisis }\end{array}$ & $\begin{array}{l}\text { Reported mortality varies, but in some series } \\
\text { amounts to } 6 \% \text { or even higher. Patients said } \\
\text { to be specially susceptible to intercurrent } \\
\text { infections }\end{array}$ \\
\hline Pathology & $\begin{array}{l}\text { Many theories held, including love-sickness } \\
\text { and sexual frustration, lack of fresh air, poor } \\
\text { diet, uterine disease, liver disease, absorption } \\
\text { of ptomaines from bowel, hypoplasia of } \\
\text { arterial system but finally believed to be } \\
\text { simply a form of hypochromic anaemia. Many, } \\
\text { however, recognised central importance of } \\
\text { psychogenic factors, including fear of obesity }\end{array}$ & $\begin{array}{l}\text { Sometimes considered an endocrine disorder, } \\
\text { especially when Simmond's disease first } \\
\text { described, but now generally accepted as a } \\
\text { psychogenic disorder associated with rejection } \\
\text { by the patient of the social and sexual implications } \\
\text { of adult life. Fear of obesity always a } \\
\text { prominent feature }\end{array}$ \\
\hline
\end{tabular}

was therefore in a different class of disease from a nervous disorder, such as anorexia nervosa.

The history of ideas concerning anorexia nervosa has recently been reviewed, ${ }^{65}$ and it is now generally agreed that it is an illness of psychogenic origin. Clear evidence of mental disturbance, whether psychoneurotic or psychotic, accompanies the illness and sometimes persists for years, leading to relapses.

Fear of obesity, which Clifford Allbutt noted in chlorosis, is prominent in anorexia nervosa and is really an irrational fear based on an erroneous perception of body image. Such self misperceptions are very common in adolescent girls and are associated with wide variations in their energy intake. ${ }^{65}$ These irrational fears are symptomatic of profound fears of the sexual and social implications of adult life. Dramatic changes in body weight and shape at puberty, and the onset of menstruation, are unmistakable signs of preparation for reproduction; if these signs generate sufficient anxiety anorexia nervosa offers an escape. Regression into childhood is symbolised by feeding problems, growing smaller, amenorrhoea, and the certainty of the extra parental and medical attention that the illness provokes. In much the same way the pica of chlorosis may have been a by asexuality. The regimen for its treatment-early hours, regularity, open air, exercise, controlled diet and emotional life-was wholesomely childlike."

He sees chlorosis as an illness resulting from nineteenth century views of adolescence as a period of "the unspoilt virtues of youth" and "as part of the bourgeois ideal of delayed marriage," while the working class contribution to chlorosis consisted of servants and others aping the respectability (symbolised by chlorosis) of their betters. ${ }^{66}$

Such evidence as exists concerning the occupation of patients that attended the dispensaries and hospital outpatients tends to support this view. Thus an account of dispensary patients with chlorosis, written in 1801, stated that: "Although a considerable number are from the poorest of the community a large proportion live as domestics in opulent families, share in the luxuries of their superiors, and experience all the bad effects of good living." 57 The conclusion is that chlorosis was a disorder bearing a close resemblance to anorexia nervosa that was found among the rich and the poor and in city and country. "The healthy country girls may show the malady less ... still, chlorosis does not pass them by." 36 
The hypothesis that is offered here is not that anorexia nervosa and chlorosis are two different names for exactly the same disorder, but rather that they are two closely related conditions, each a manifestation of the same type of psychological reaction to the turbulence of puberty and adolescence. It is, admittedly, a hypothesis that flies in the face of orthodox belief. Anorexia nervosa is generally considered as a "modern" disorder, sometimes described as a form of deviant behaviour characteristic of the pampered middle classes of an affluent society. Chlorosis, on the other hand, is generally regarded as having been an organic disease, an anaemia, characteristic of the oppressed working class in the nineteenth century. If the hypothesis presented in this paper, however, is accepted as broadly correct it has implications of great interest. Not only is the stereotyped picture of chlorosis incorrect, but anorexia nervosa may not be a "modern" disorder in historical terms. The "morbus virgineus" of Lange, the green sickness and chlorosis may be thought of as disorders lying on the same evolutionary line of psychopathology as anorexia nervosa. When one considers that the time from Lange's description to the present is over 400 years it is the underlying similarity of these disorders rather than the differences that is striking. Perhaps the mystery of the "Cheshire cat" phase is really not a mystery at all: though it faded from sight it is, in this story, still there under another name.

This paper arose from a historical study of dispensaries and outpatients supported by a grant from the Wellcome Trust which I gratefully acknowledge. I thank all who helped in the preparation of this paper, particularly Dr Charles Webster, director of the Wellcome Unit for the History of Medicine in the University of Oxford, Professor L J Witts and Dr A H T Robb Smith for advice and permission to quote from their clinical experience; and $\mathrm{Mr}$ John Bateman, classics master at King Alfred's School, Wantage, for his skill in translation. Most of all, I am grateful to my partners without whose generous and willing help this work could not have been undertaken.

\section{References}

'McFarland RE. The rhetoric of medicine: Lord Herbert's and Thomas Carew's poems of green-sickness. F Hist Med 1975; July: 250-8.

2 Vertue H St H. Chlorosis and stenosis. Guy's Hospital Reports 1955;104 329-48.

3 Oxford English Dictionary, under "chlorosis" and "green-sickness."

4 Witts LJ. Hypochromic anaemia. London; Heinemann Medical, 1969.

5 Campbell JMH. Chlorosis. A study of Guy's Hospital cases during the last thirty years. Guy's Hospital Reports 1923;73:247-97.

- The author is indebted to Dr A H T Robb Smith for this apt description of the fourth phase.

7 Buchan W. Domestic medicine. Edinburgh: 1769.

8 Ashwell Dr. Observations on chlorosis and its complications. Guy's Hospital Reports No 1, Sept 1836: pp 529-79.

9 Hirsch A. Handbook of geographical and historical pathology. Trans by C Creighton. New Sydenham Society 1885;2:492-501.

10 The Bristol Mercury. "Welsh's female pills ... to remove obstructions to which unmarried females, at a certain period, are subject; also, what is commonly known as the green sickness." $1790 \mathrm{Dec} 21$.

11 Monthly Magazine 1800; No 58:392.

12 Cullen in First lines .. of physic (3rd ed. 1781) called primary amenorrhoea "retention of the menses" and secondary amenorrhoea ("after they have repeatedly taken place for some time, they do from other causes than conception, cease to return at their usual periods") "suppression of the menses." Most authors of the eighteenth and early nineteenth centuries, however, used the terms retention, suppression, or obstruction of the menses interchangeably.

${ }^{13}$ Fox S. Observations on the disorder of the general health of females called chlorosis. London: 1839

14 The second morbidity survey from general practice. Studies on medical and population subjects. No 36. London: HMSO, 1972.

15 Fry J. Common diseases. Lancaster: MTP Press, 1972

16 Osler W. Principles and practice of medicine. 1st ed. 1892.

17 Lettsom JC. Medical memoirs of the general dispensary. London; 1774.

${ }^{18}$ Millar J. Observations on the practice in the medical department of the Westminster General Dispensary. London: 1777

19 The Monthly Magazine. 1800-1801.

20 The Monthly Magazine. 1812.

21 Willan R. Reports on the diseases of London. London: 1801.

22 The London Medical and Physical fournal 1805;5:383.

23 The Medical and Physical fournal. 1801-1802.
24 Woolcombe W. Remarks on the frequency and fatality of different diseases. London: 1808.

${ }^{25}$ Edinburgh Medical and Surgical fournal 1809;5:383.

26 Whitelow and Walsh, History of Dublin, London 1818, quoted in F Bisset Hawkins, Elements of medical statistics. London: 1829.

27 Medical and Physical fournal $1800 ; 3,4,1801 ; 5$.

28 Clark J. Edinburgh Medical and Surgical fournal 1807;3:309.

${ }^{29}$ Lange J. De morbo virgineo. Epistola XXI, Epistolae Medicinales 1554 Trans from Ralph Major. Classic descriptions of disease. 2nd ed. Springfield and Baltimore: Chas C Thomas, 1932.

${ }^{30}$ Lettsom JC. Hints respecting the chlorosis of boarding schools. 1795.

${ }^{31}$ Laycock T. A treatise on the nervous diseases of women. London, 1840.

32 Scott R. On chlorotic affections. Medical and Physical fournal 1800;3 : 107-8, 215-6.

${ }^{33}$ Gaillard TT. A practical treatise of the diseases of women. 4th ed. London and Philadelphia, 1875.

${ }^{34}$ Blane G. Select dissertations on several subjects of medical science. New ed. $1833 ; 1$ :dissertation III.

35 Willan R. Reports on the diseases of London. London, 1801.

${ }^{36}$ Albutt TC. A system of medicine by many writers. London, 1898;5 :479-517.

37 Stockman R. Observations on the causes and treatment of chlorosis. Br Med 7 1895 ;ii:1473-6.

38 Osler W. Principles and practice of medicine. 4th ed. Philadelphia, 1898

${ }^{39}$ Barker Dr. Clinical remarks on cases of chlorosis. London Medical Gazett $1843-4 ; 1: 353-6$.

40 Cleveland J. Poems. 42. 1651. "Why, my muse, like a green-sickness girl feedest thou on coals and dirt." Johnson, Ben. The Magnetic Lady. Act 1, Sc 1 "She can cranch a sack of small coal, eat your lime and hair, soap, ashes loam and has a dainty spice of the green sickness." 1632.

41 Varandhal J. De affectibus mulierium. 1619.

42 Quincy J. Lexicon physico-medicum. 4th ed. London, 1730.

43 Cullen W. First lines in the practice of physic. 3rd ed. Edinburgh, 1781.

${ }^{44}$ Hooper R. Lexicon medicum. London; 1825.

45 Hall M. Commentaries principally on those diseases of females which are constitutional. London: 1830.

${ }^{46}$ Forbes A, Tweedie A, Connolly J. The cyclopaedia of practical medicine. London: 1833.

47 Mayne RG. Expository lexicon. London: 1860.

48 Churchill F. On the diseases of women. 5th ed. Dublin: 1864.

49 Power H, Sedgwick LW. The New Sydenham Society's lexicon of medicine and allied sciences $1881 ; 1$.

50 Quain R. A dictionary of medicine. Part 1. London: 1882.

51 Naegli O. Blutkrankheiten und blutdiagnostic. 1908. Die chlorose 376-87.

52 Cabot RC. In: Osler W, McCrae T, eds. Modern medicine. Philadelphia; 1925.

53 Pyke DA. Finger clubbing: validity as a physical sign. Lancet 1954 :ii : 352-4 provides a good example of the force of bias in clinical signs.

54 Stevenson RL. Virginibus puerisque. 1881.

55 Hudson RP. The biography of disease: lessons from chlorosis. Bulletin of the History of Medicine 1977;51:448-63.

56 Jewson ND. The disappearance of the sick man from the medical cosmology 1770-80. Sociology $1976 ; 10$, No $2: 225-44$.

57 Reid J. Monthly Magazine. $1801 ; 11: 251$.

58 Robb Smith AHT. The history of the hedgehog's rosary. Part 3. St Bartholomew's Hospital fournal 1933;40;212-3.

59 Marshall Hall (ref 45 above) considered that chlorosis in an advanced stage resembled the effects of blood loss, and Bland in 1832 suggested chlorosis might be due to a "faulty formation of the blood."

${ }^{60}$ Reiser SJ. Medicine and the reign of technology. Cambridge University Press, 1978

61 Parrot J. Chlorose in Dictionnaire Encyclopedique des Sciences Medicales. 1 ere serie 16. Paris;1874:699-719.

62 Bristol Royal Infirmary. Inpatient registers. Bristol Royal Infirmary Archives; Bristol Record Office, The Council House, Bristol.

63 Gull WW. "A collection of the published writings of ...." Reprinted from Clinical Society's Transactions $1874 ; 7: 22$. Edited and arranged by T D Acland. London; New Sydenham Society, 1894.

64 Dally P, Gomez J, Issaacs AJ. Anorexia nervosa. London: Heinemann, 1979.

65 Lacy JH, Chadbund C, Crisp AH, Whitehead J, Stordy J. Variation in energy intake of adolescent schoolgirls. F Hum Nutr 1978;32:419-26.

${ }^{66}$ Figlio K. Chlorosis and chronic disease in nineteenth-century Britain: the social constitution of somatic illness in a capitalist society. Social History May $1978 ; 3$ No 2:167-97.

(Accepted 14 March 1980)

ONE HUNDRED YEARS AGO

The following is from the New York Hospital Gazette:-I don't know with whom originated the brilliant idea of employing local anaesthesia (with ether) just before the cautery is applied, but I have heard that a distinguished physician relates the following personal experience. Desiring to cauterise a patient's spine, he applied the ether in spray until he deemed the part sufficiently frozen. He then applied the cautery. The ether took fire and scorched some of the patient's hair. When asked how the patient liked it, he replied that the patient supposed it was all right, and "a part of the regular pyrotechnics." (British Medical fournal, 1880.) 